\title{
The Work Creation Law Legislation Process
}

\author{
Petrus Yakobus Bapa, Efrizal HS, Hedwig Adianto Mau, Ramlani Lina Sinaulan \\ Program Studi Magister Ilmu Hukum \\ Fakultas Hukum, Universitas Jayabaya \\ petrusyakobusbapa@gmail.com \\ efrizalhs@gmail.com \\ hedwigadiantomau@gmail.com \\ ramlani_ls@jayabaya.ac.id
}

Received: 04 Januari 2021; Revised: 26 Februari 2021; Accepted: 28 April 2021 DOI: http://dx.doi.org/10.37905/aksara.7.2.667-680.2021

\begin{abstract}
Abstrak
Problem hukum termuat dalam proses pembentukan Pembentukan UndangUndang Republik Indonesia Nomor 11 Tahun 2020 Tentang Cipta Kerja. Kritik dari masyarakat bermunculan pasca draft rencana undang-undang itu diusulkan ke Dewan Perwakilan Rakyat dan telah diundangkan, karena ada beberapa kekeliruan didalam proses pembentukan. Penelitian ini akan mengkaji proses pembentukan Undang-Undang Cipta Kerja dilihat dari Asas-Asas Pembentukan Peraturan Perundang-undangan Yang Baik sebagaimana dimaksud dalam Undang-Undang Republik Indonesia Nomor 12 Tahun 2011 tentang Pembentukan Peraturan Perundang-undangan. Adapun metode yang digunakan adalah normatif dan pendekatan kasus. Hasil penelitian ditemukan dalam proses pembentukan Undang-Undang Cipta Kerja tidak sesuai dengan asas-asas sebagaimana diatur dalam undang-undang Undang-Undang Republik Indonesia Nomor 12 Tahun 2011 tentang Pembentukan Peraturan Perundang-undangan.
\end{abstract}

Kata Kunci: asas-asas, pembentukan undang-undang, cipta kerja

\begin{abstract}
Legal problems are contained in the process of formation of the Constitution of the Republic of Indonesia Number 11 of 2020 on Job Creation. Criticism from the public emerged after the draft draft law was proposed to the House of Representatives and was postponed, as there were some errors in the formation process. This research will examine the process of forming the Law of Creation as seen from the Principles of the Establishment of Good Legislative Regulation as referred to in the Law of the Republic of Indonesia Number 12 of 2011 on the Establishment of Legislative Regulations. The methods used are normative and case approach. The results of the research were found in the process of making the Law of Copyright created in accordance with the principles as regulated in the Law of the Republic of Indonesia Number 12 of 2011 on the Establishment of Legislation
\end{abstract}

Keywords: basics, law making, job creation 


\section{INTRODUCTION}

Article 1 paragraph (3) of the 1945 Constitution of the Republic of Indonesia explicitly states that, "The State of Indonesia is a constitutional state." The consequence of the mandate of the constitution is that Indonesia wants to adhere to the concept of a rule of law in carrying out all aspects of state life. The idea of the rule of law has actually long been developed by philosophers from Ancient Greece. Plato, initially in the Republic argued that it is possible to create an ideal state to achieve good which is essentially good. However, in his book The Statesman and the Law, he states that what can be realized is the second best form that places the rule of law. The goal of the state according to Aristotle is to achieve the best life (the best life possible) which can be achieved through the rule of law. Recognition of the principle of the rule of law, namely placing the law as the holder of the highest command in state administration. Therefore, it can be understood that the rule of law as a concept is a state tool to achieve its goals. (Jimly Asshiddiqie, 2012).

Law is a legal regulatory instrument in a rule of law. The main purpose of the existence of law according to Mochtar Kusumaatmadja (2002) is the guarantee of order, justice and certainty. Thus, law is a system that has characteristics and characteristics that become the driving and regulator of community life. The law manifests in the form of statutory regulations, a set of written laws in various forms that regulate all aspects of state and social life. According to Mahfud MD (2009), laws and regulations are all laws in a broad sense that are formed in a certain way by an authorized official and set forth in a written form. Along with developments, the principles of a rule of law are also influenced by the acceptance of the understanding of people's sovereignty and democracy. The rule of law and people's sovereignty are exercised as two sides of one coin. This understanding of a rule of law is called a democratic rule of law (democratische rechstaat). Laws are built and enforced based on democratic principles. On the other hand, democracy must be regulated based on law. Therefore, law as a regulating instrument, although the estuary of its regulation is also aimed at every citizen, its formation cannot be separated from the participation of citizens, either directly or indirectly, in a bandage of democratic principles.

With regard to statutory regulations as the embodiment of written law, Bagir Manan (1992) has explained that one of the elements of statutory regulations is general binding and in written form so that it can also be called written law. Whereas on another characteristic, statutory regulations usually have various types, and each form of statutory regulation is arranged hierarchically. Forming a statutory regulation certainly requires a good plan or plan to determine the direction in which the statutory regulation is formed. With a good plan, a good statutory regulation will also be formed. In planning the formation of laws and regulations, of course, what is called a concept. This concept will later have an active role in shaping good laws and regulations. Can form a statutory regulation that has certainty, fairness and benefits. The formation of statutory regulations certainly requires a concept as initial capital in forming good statutory regulations. This concept will later direct the rules of law that are formed into good, directional laws that have justice, certainty and can distribute benefits. The 
Unitary State of the Republic of Indonesia (hereinafter abbreviated as NKRI) is a constitutional state that requires a concept in shaping law. The applicable law, if it is formed using a good concept, which is well planned, then the law in the form of statutory regulations owned by the Republic of Indonesia will be a good law that reflects justice. Therefore, the concept of the formation of statutory regulations is very important in forming a good statutory regulation. The concept of the formation of laws and regulations in Indonesia must be strictly in accordance with the basic norms and principles in the formation of statutory regulations. Thus, the formation of statutory regulations will form laws in accordance with the ideals of Indonesian law itself by putting forward a good concept in forming a good statutory regulation, which is able to regulate, safeguard and protect all Indonesian people, nation and state. (Lutfil Ansori, 2009).

There is a phenomenon with regard to statutory regulations that has now surfaced and aroused debate, when the government submitted the Draft Work Creation Bill (RUU) to the House of Representatives. The debate over this matter arose without reason, because the Draft Job Creation Bill was formed by the government through the Omnibus Law. Not only that, even out of the 50 Draft Laws that were included in the 2020 National Legislation Program (Prolegnas), four of them are the omnibus law which consists of the Bill on the National Capital, the Bill on Pharmacy, the Bill on Job Creation, and the Bill on Taxation Provisions and Facilities for Economic Strengthening. Laws are statutory regulations established by the House of Representatives with the joint approval of the President. Law as a type of statutory regulation is a place to further detail the legal norms contained in the Basic Law. Law is also a form of statutory regulation with the widest range of material content. In fact, there is almost no field of community and government life that cannot be regulated by law. As for the Omnibus Law, etymologically the word omnibus is usually juxtaposed with the word law or bill which means a rule made based on the compilation of several rules with different substances and levels. It can be said that the omnibus law is a method or concept of making legislation that combines several rules with different regulatory substances, into a large regulation that functions as an umbrella act, and when the regulation is promulgated the consequences of changing or changing some of the rules resulting from the merger are good. in part or as a whole. (Paulus Aluk Fajar Dwi Santo, 2020). Omnibus law is nothing new. The implementation of the omnibus law method has existed and is closely related to the formation of laws in countries with the Anglo Saxon legal tradition. However, when this method was adopted by the Indonesian government in the formulation of the draft law, the omnibus law is now transformed into a legal discourse in Indonesia. Apart from the pretext on behalf of certain goals to be achieved according to the government through the application of the omnibus law method, it is necessary to critically analyze the omnibus law method both in terms of concept and implications for practice. Given that there are several deficiencies present in omnibus law when it is applied as a method in the formation of statutory regulations. As is well known, the House of Representatives (DPR) approved the Work Creation Omnibus Law Bill on October 5, 2020 and then on November 2, 2020 it was signed by President Joko Widodo. The Job Creation 
Law, which from its inception caused a lot of debate, was finally officially ratified and promulgated in the Law of the Republic of Indonesia Number 11 of 2020 concerning Job Creation. Based on the description above, questions arise regarding the issues raised in this study, including: What are the foundations and principles for the formation of laws and regulations in Indonesia? Is the formation of Law of the Republic of Indonesia Number 11 of 2020 concerning Job Creation in accordance with the principles of formation according to Law of the Republic of Indonesia Number 12 of 2011 concerning the Formation of Legislation?

\section{RESEARCH METHODS}

The approach method used in this research is normative and case approach. The legal approach is taken by reviewing the Law of the Republic of Indonesia Number 11 of 2020 concerning Job Creation and Law Number of the Republic of Indonesia Number 12 of 2011 concerning the Formation of Laws and Regulations as well as a case approach regarding the process of establishing Laws that occurs in the Council People's Representative. This study uses qualitative methods with literary and empirical approaches. Data obtained through analysis of laws and phenomena that occur.

\section{RESULTS AND DISCUSSION}

\section{a. Foundations and Principles for the Formation of Legislative Regulations.}

The formal aspect is also called the procedural aspect which relates to the formal constitutional foundation for the formation of statutory regulations. Meanwhile, the material aspect relates to the content material which must and is suitable to be regulated in legislation according to the type and level (hierarchy) and in accordance with what is ordered either explicitly or implicitly in the Basic Law and / or based on the principle of constitutionality. The formal constitutional foundation is intended to provide procedural legitimacy for the formation of statutory regulations. In the context of the formation of statutory regulations which are stipulated by the 1945 Constitution (UUD 1945), the formal constitutional foundation is the articles in the 1945 Constitution which signal the procedures for its formation. The constitutional material foundation is intended to provide a signal that the legislative regulations that are formed are the elaboration of the articles of the 1945 Constitution and / or the laws and regulations under the 1945 Constitution which are the elaboration of the articles of the 1945 Constitution.

The formation of statutory regulations must pay attention to the principles of its formation, namely:

1. Philosophical basis, namely the basis of philosophy or views of ideas which are the basis of ideals when pouring desires and policies into a plan or draft of legislation.

2. Sociological basis, is the basis for making laws and regulations whose contents provide an indication of facts or real conditions that occur in society. 
3. Political foundation, which is a line of political policies which becomes the next basis for policies and direction for the management of the state government.

4.Juridical basis, is a legal provision that becomes the legal basis for making regulations including the authority to make laws and regulations, whether the authority of an official or an agency / institution.

In relation to the aforementioned basis for making statutory regulations, the rules that need to be considered in the preparation of statutory regulations which are the juridical basis are:

a. Every legal product must be made by an authorized official.

b. The necessity of having the conformity of the form or type of legal products with the regulated material, especially if it is higher or equal.

c. Must follow certain ordinances.

d. The necessity does not conflict with laws and regulations of a higher level.

e. Legal products made for the public interest must be accepted by society naturally and spontaneously.

In preparing good laws and regulations according to I.C. Van Der Vlies and A. Hamid S. Attamimi are divided into 2 (two) classifications, namely formal principles and material principles. Formal principles include: clear purpose principles or beginsel van duideleijke doelstelling; principles of appropriate organs / institutions or beginsel van het juiste orgaan; the principle of the need for arrangements or het noodzakelijkheids beginsel; the principle of enforceability or het beginsel van uitvoerbaarheid; principle of consensus or het beginsel van consensus. Meanwhile, material principles include: principles regarding correct terminology and systematics or het beginsel van duidelij to en duidelijke systematiek terminology; the principle of recognizable or het beginsel van de kenbaarheid; the principle of equal treatment in law or het rechtsgelijkheidsbeginsel; principle of legal certainty or het rechtszekerheids beginsel; the principle of implementing the law according to individual circumstances or het beginsel van de individuuele rechtbedeling.

The opinion above, if it is related to the distribution of formal and material principles that are in accordance with the principles of the rule of law in Indonesia, then the division can be grouped, namely the formal principle which includes the principle of clear objectives, the principle of the need for regulation, the principle of the right organ or institution, the principle of the right material content., principles can be implemented, and principles can be recognized. Meanwhile, those included in material principles are principles in accordance with the ideals of Indonesian law and fundamental state norms, principles in accordance with the basic laws of the country, principles in accordance with state principles based on law, and principles in accordance with the principles of governance based on the constitution. In forming statutory regulations, it must be carried out based on the principles of the formation of good statutory regulations, including: clarity of objectives, appropriate institutional or forming officials and conformity between types, hierarchies and material content that can be implemented and efficiency and efficiency, clarity of formulation and openness. In addition, the content contained in statutory regulations must reflect the 
principles of protection, humanity and nationality as well as kinship, nationality, diversity, justice and equality in law and government, order and legal certainty as well as balance, harmony and harmony. The principles for the formation of statutory regulations above reflect a sound statutory form. If it is applied into a statutory regulation, a good statutory regulation will be formed which is in accordance with the principles already stated in the law without leaving the principles of justice. Meanwhile A. Hamid S. Attamimi has an opinion regarding the formation of good laws and regulations. Attamimi's opinion states that, the proper formation of Indonesian laws and regulations is as follows: The Ideals of Indonesian Law; State Principles Based on Law and Government Principles based on the Constitution; Other principles.

The formation of laws and regulations must prioritize clarity of purpose, in the sense that the objectives of the formation of these laws and regulations must be clear, fulfill the wishes of the public at large in order to create equitable certainty so as to distribute benefits to all Indonesian people. In addition, the concept of the institution or official forming legislation must be a credible institution, which is democratically recognized by the public at large. The formation of statutory regulations must adjust the type, hierarchy, and content of the content as well as the principles in accordance with the basis for the formation of statutory regulations. Principles are the basis or foundation in determining attitudes and behavior. The principles of forming statutory regulations are the basis for the formation of statutory regulations and policy makers in shaping statutory regulations. All principles must be imprinted in the policy maker who will form the statutory regulations. In the formation of statutory regulations, of course, requires a principle or basis in forming a statutory regulation. In the formation of laws and regulations of the Republic of Indonesia which are based on Pancasila as its fundamental basis. The concept of the rule of law Pancasila is the concept of the original rule of law from Indonesia which is the main principle in the formation of laws and regulations in Indonesia. The concept of the rule of law Pancasila plays an important role in realizing the laws and regulations in Indonesia.

The principle adopted from the concept of the rule of law, Pancasila, has the truth that has been recognized by the Indonesian people since ancient times until now. The concept of the rule of law, Pancasila, is undoubtedly true in realizing the principle of the formation of statutory regulations in Indonesia. The principles in the concept of the rule of law Pancasila can be translated and realized into principles for the formation of good laws and regulations, which create certainty, justice and benefits for all Indonesian people. The principle of forming laws and regulations must adhere to the principles of forming good laws and regulations in accordance with the principles of justice. Principles are norms that must be embodied in statutory regulations and which apply forcefully. The principles for the formation of good statutory regulations include the following: Legislation is not retroactive; Legislation made by a higher authority, having a higher position, this is in accordance with the statutory hierarchy; Legislation that is specific in nature overriding the statutory regulations that are general in nature; The prevailing laws and regulations cancels the prevailing laws and regulations; 
Legislation cannot be contested, in the sense that law is a reflection of justice which must be recognized by all parties; and Legislation as a means to the maximum extent possible to achieve spiritual and material welfare for society and individuals, including as a means of obtaining justice.

The principles for the formation of laws and regulations can be divided into two principles, namely formal principles and material principles. Formal principles include principles of clear objectives for justice, principles for proper institutions to form laws, principles for regulatory needs, principles for implementation, and principles for consensus. Meanwhile, the principles of materiality are the principles of correct terminology and systematics, the principles of recognition, the principles of equal treatment in law, the principles of legal certainty, and the principles of law enforcement in accordance with individual circumstances. In forming statutory regulations, it must be carried out based on the principle of the formation of good statutory regulations including clarity of purpose in forming statutory regulations, appropriate institutions or forming officials who are credible institutions elected democratically by the people as holders of state power. type, hierarchy, and content, can be implemented, efficiency and efficiency, clarity of formulation, and openness. The content contained in statutory regulations must reflect the principles of protection, humanity, nationality, kinship, nationality, diversity, justice, equality in law and government, legal order and certainty, and / or balance, harmony and harmony. The formation of good Indonesian laws and regulations must prioritize the ideals of Indonesian law in taking the idea of realizing just certainty. In addition, the state principle that is based on law is an appropriate basis for the creation of good legislation. As a legal state that has a legal level, it must prioritize the hierarchy of legislation in the formation of statutory regulations, especially the constitution as the highest law.

In the formation of laws and regulations in Indonesia, it must be guided by the following:

1. The ideology of the nation, namely the ideals of Indonesian law which is none other than Pancasila;

2. The State Fundamental Norms are none other than Pancasila;

3. The principles of the state are based on law and the principles of government are based on the constitution.

In addition to the three guidelines that have been mentioned above, there are several principles used in the formation of laws and regulations which include the basis of statutory regulations always using statutory regulations as a reference for the formation of statutory regulations, only certain laws and regulations are can be used as a juridical basis for the formation of statutory regulations, statutory regulations that are still in effect can only be removed, revoked or amended by laws of an equivalent or higher legislation, and new laws override legislation. old invitation or Lex posterior derogat legi priori.

The principle of forming good laws and regulations based on Article 5 of the Republic of Indonesia Law Number 12 of 2011 concerning the Formation of Legislation (UU P3) includes: 


\section{Clarity of purpose}

this principle implies that every formation of laws and regulations must have clear objectives to be achieved;

2. Institutional or proper formation organs

This principle implies that every type of statutory regulation must be made by an authorized state institution or official forming the legislation. These statutory regulations can be canceled or null and void if they are made by unauthorized state institutions or officials;

3. Compatibility between the type and material of charge

this principle implies that in the formation of statutory regulations, the appropriate content material must be considered in accordance with the type and hierarchy of the statutory regulations;

4. Can be implemented

this principle implies that every formation of laws and regulations must take into account the effectiveness of these laws and regulations in society, both philosophically, sociologically, and juridically;

5. Efficiency and efficiency

this principle means that every statutory regulation is made because it is truly needed and useful in regulating the life of the community, nation and state;

6. Clarity of formulation

this principle means that every statutory regulation must meet the technical requirements for drafting statutory regulations, systematics, choice of words or terms, as well as clear and easy to understand legal language so as not to cause various kinds of interpretations in its implementation;

7. Openness.

This principle implies that in the formation of laws and regulations starting from planning, preparation, discussion, ratification or stipulation, and promulgation are transparent and open. Therefore, all levels of society have the widest possible opportunity to provide input in the formation of laws and regulations.

Meanwhile, according to Article 6 of the P3 Law, it states that the contents of the legislation must reflect the principles of:

1. Protection

This principle implies that every material contained in statutory regulations must serve to provide protection to create public order.

2. Humanity

This means that every material contained in the laws and regulations must reflect the protection and respect for human rights as well as the dignity and worth of every citizen and population of Indonesia in a proportional manner.

3. Nationality

This means that every material contained in the statutory regulations must reflect the character and character of the diverse Indonesian nation while maintaining the principles of the Unitary State of the Republic of Indonesia. 


\section{Kinship}

means that every material contained in the legislation must reflect deliberation to reach consensus in every decision-making.

5. Archipelago

This means that every material content of statutory regulations always takes into account the interests of the entire territory of Indonesia and every material content of legislation made in the regions is part of the national legal system based on Pancasila and the 1945 Constitution.

\section{Unity in diversity}

This means that any material contained in statutory regulations must take into account the diversity of the population, religion, ethnicity and class, regional special conditions and culture in the life of society, nation and state.

7. Justice

means that every material contained in the legislation must reflect justice proportionally to every citizen, justice in accordance with the basic norms of the nation.

\section{Equal position in and government}

means that any material contained in statutory regulations must not contain anything that is discriminatory based on background, among others, religion, ethnicity, race, class, gender, or social status.

9. Order and legal certainty

means that every material contained in the legislation must be able to create order in society through a guarantee of certainty

10. Balance, seriousness and harmony

means that every material contained in laws and regulations must reflect the balance and harmony between the interests of individuals (individuals), society and the interests of the nation and the State.

After fulfilling the principles of statutory regulations, the form of statutory regulations can be implemented in the sense that the statutory regulations that have been formed can be applied and implemented as a legal basis for a constitutional state that upholds the rule of law. The next concept relates to benefits, namely the efficiency and effectiveness of the laws that are formed must provide benefits. The clarity of the formulation in the substance of statutory regulations is a basic concept in forming a good statutory regulation and the last one is the transparency of the legal concept regulated in statutory regulations which is known and acknowledged by all people who are the subject of the law.

The concept of the content of laws and regulations must be able to provide protection for Indonesian people in general. Concerning the life of the nation and the state contains the principle of kinship and unity of diversity which raises justice based on Pancasila as the philosophy and ideology of the Indonesian nation which provides legal protection to all Indonesian people by adhering to the principle of equality before the law. The concept of justice is expected to provide realization for legal justice that is accepted by the community. Legal justice can be accepted by society if the formation of law adheres to the principles and values of justice in its formation. Justice that has good principles of justice, namely 
justice in the form of values that provide equality for all Indonesian people regardless of the services and conditions of the citizens' social status. Justice from the values of Pancasila is then realized into legal norms and becomes a justice that can be recognized as true because the formation of laws and regulations is formed in a fair way. The basic concept of laws and regulations based on Pancasila, prioritizes human rights including the right to justice for citizens and provides equality before the law for all Indonesian people. This concept is certainly a guideline for the formation of laws and regulations that are good for the nation and state of Indonesia, creating certainty that adopts the values of Pancasila so that it can distribute benefits to all Indonesian people. Justice will be realized if we always prioritize human rights that come from Pancasila which are the principles of justice. The formation of good laws and regulations will follow the basis given by the ideals of the rule of law, namely Pancasila. If Pancasila is connected with the division of formal and material principles, then the distribution can be concluded as formal principles in accordance with Pancasila including clear objectives, the need for regulation, the right organs or institutions, the right content material principles, the principles can be implemented, and principles can be recognized. Meanwhile, the material principles include principles in accordance with the ideals of Indonesian law and state fundamental norms, principles in accordance with the basic laws of the country, principles in accordance with state principles based on law, and principles in accordance with the principles of governance based on the constitution.

\section{b. Application of the Principles of Establishing Good Legislation in the Law of the Republic of Indonesia Number 11 of 2020 Concerning Job Creation \\ 1. Principle of Clarity of Purpose}

The explanation of the "principle of clarity of objectives" in Article 5 letter a of the P3 Law is that every legislative formation must have clear objectives to be achieved. If we look at the purpose of the creation of the Job Creation Law, it is contained in Article 3 which states:

This Law was formed with the aim of:

a. creating and increasing employment opportunities by providing convenience, protection and empowerment for cooperatives and MSMEs as well as national industry and trade as an effort to be able to absorb the widest possible Indonesian workforce while still paying attention to the balance and progress between regions in the national economic unity;

b. guarantee that every citizen can obtain a job, and receive compensation and fair and decent treatment in an employment relationship;

c. make adjustments to various regulatory aspects related to alignments, strengthening, and protection for cooperatives and UMK-M as well as national industry; and

d. make adjustments to various regulatory aspects related to improving the investment ecosystem, facilitating and accelerating national strategic projects oriented towards national interests based on national science and technology based on the ideology of Pancasila. 
However, the norm provisions stipulated in the Job Creation Law are contradictory with the aim of the creation of the Job Creation Law, meaning that it will not arrive at the goal to be achieved. As an example of the purpose of the creation of the Job Creation Law as regulated in Article 3 letter b, it is clearly and clearly not in accordance with the content material regulated in it. For example, in the provisions of the labor sector, there are articles that are detrimental to workers so that they do not receive fair and proper treatment in work relations. Against the provisions of the article norms in the Job Creation Law which do not provide guarantees for workers / laborers to get fair and proper remuneration and treatment in a work relationship, namely:

a. The Job Creation Law removes the rules regarding the period of a certain time work agreement (PKWT) or contract workers as regulated in Article 59 paragraph (4) of the Manpower Law. This of course eliminates the opportunity for citizens to get an indefinite work agreement (permanent job);

b. In the Manpower Act, Entrepreneurs are obliged to provide weekly rest of 1 (one) day for 6 (six) working days in 1 (one) week or 2 (two) days for 5 (five) working days in 1 (one) week. Meanwhile, the Job Creation Law is only given a weekly break of 1 (one) day for 6 (six) working days in 1 (one) week.

c. In the Manpower Law there are 11 (eleven) wage policies, while the Job Creation Law is trimmed down to 8 (eight) wage policies.

d. Sanctions for employers who do not pay wages in accordance with the provisions stipulated in the Manpower Law are removed by the Job Creation Law.

e. In the Manpower Act, the calculation of severance pay uses the least size, meaning that there is a minimum limit. Meanwhile in the Job Creation Law, the phrase at least is changed to be the most so that there is no limit to the calculation of severance pay received by workers / workers.

f. In the Manpower Act, workers can submit an application for dismissal to the PPHI Institution in the event that the employer commits the actions set forth in letter a to letter f. Regarding the dismissal, the worker / laborer receives severance pay, an award and compensation for rights. However, Article 169 of the Job Creation Law is deleted;

If we look at some of the provisions of the norms mentioned above, the Job Creation Law in its formation has violated the Principle of Clarity of Purpose as mandated by Article 5 letter a of the P3 Law. This means that the objective of ensuring that every citizen receives fair and proper remuneration and treatment in a work relationship, provided that the norms governing work relations in the Job Creation Law are actually contradictory.

\section{Principle of Usability and Usability}

If we look at the utility and efficiency of the Job Creation Law, of course it is clearly inappropriate and has violated the utility and efficiency as referred to in Article 5 letter e of the P3 Law. This can be seen from the merger of 78 laws which of course have basic ideas that contain different philosophical, juridical, and sociological elements, but are put together by using the Omnibus Law concept 
without conducting in-depth research, and without involving parties. -parties and Academic Drafts that are not in-depth and not comprehensive.

\section{Principle of Clarity of Formulation}

a. Title aspect. If you explore the contents of the draft, there are three types of regulations, namely forming new norms, changing norms and / or removing norms, and revoking laws. If the draft is intended to make a new law at all, the title "Job Creation" will not matter. However, when most of the drafts actually amend / delete the norms in the law, the title becomes irrelevant. The provisions in the attachment to the Law on the Establishment of Legislations explicitly state that the title of the amended law must contain the title of the law being amended. Included in the case of law repeal, the title of the law being revoked must also be mentioned.

b. The preamble to the formation of laws should only contain philosophical, sociological and juridical considerations. However, in that draft, in the preamble, a consideration of technical issues in the formation of a law appears. It is stated that changes in sectoral laws are considered ineffective and inefficient, so legal breakthroughs are made through the omnibus law method. From this formulation, the government mistakenly places criticism on the technicalities of changing the law as a prejudice to changing laws that regulate substantive matters. If the government feels that the process and technique of changing laws is difficult, what should be amended first is the law that regulates the formation of statutory regulations.

c. Basic legal aspects of the formation of laws. Although most of the substance of the draft contains changes to various laws, none of the laws to be amended are used as the legal basis. Usually, in every amendment, the law to be changed is made as part of the legal basis.

d. Structural aspects of the legal formulation are systematically arranged in sequence, (i) general provisions, (ii) subject matter regulated, (iii) criminal provisions (if necessary), (iv) transitional provisions (if needed), and (v) closing. In that draft, the systematic formula could not be used because it used the omnibus law method, which changed many laws. Thus, the section or chapter "general provisions" which should have been placed in the initial article or several articles cannot be applied because they are spread across all parts of the law based on the order in which the laws are to be changed or deleted. The same thing then also affects other parts which are all scattered and not structured systematically.

\section{The Principle of Openness}

Not all discussions are conducted openly. The openness and involvement of elements of society that was seen in the mass media during the discussion of the Job Creation Law was only seen in the community in the labor sector. Even then, there are still many elements of workers' association organizations who feel they are not being involved. One example is the discussion regarding the Protection of Indonesian Migrant Workers that does not involve groups of the Indonesian migrant worker community, such as the Indonesian Migrant Workers 
Union (SBMI), the Migrant CARE organization and other migrant worker organizations. This is one example in an employment cluster that was not involved and there are many more examples of parties who were not involved in the process of its formation. In addition, the Principle of Openness must also be transparent to every stage, starting from the planning, drafting, discussion, ratification or stipulation stages to enactment.

Basically, transparency is manifested in the form of public participation as referred to in Article 96 of the P3 Law which states:

(1) The public has the right to provide input orally and / or in writing in the Formation of Legislation.

(2) Verbal and / or written input as referred to in paragraph (1) can be made through:

a. public hearing meetings;

b. work visit;

c. socialization; and / or

d. seminars, workshops, and / or discussions.

(3) The community as referred to in paragraph (1) is an individual or group of people who have an interest in the substance of the Draft Legislation.

(4) To facilitate the public in providing input orally and / or in writing as referred to in paragraph (1), each Draft Legislation must be easily accessible to the public.

But in reality, if we see that the process of establishing the Job Creation Law does not meet the requirements of public participation, including access to easily obtain the Job Creation Bill, it is not fulfilled, especially with the circulation of 5 drafts of the Job Creation Bill with different substances. With so many sheets it confuses the public (individuals or groups of people) to provide input.

\section{CONCLUSION}

Violation of the principles and formulation of the statutory regulations on Job Creation clearly shows the violations committed by the government towards the Formation of Legislation. It is as if the Job Creation Law was forced because the government and the House of Representatives based it on the interest of facilitating discussions for both parties only, without considering the problems experienced by the community as the object of this regulation. The process of establishing laws that have been under the authority of the government and the House of Representatives has not been corrected. Even when this draft was finally discussed, how ready were the internal rules of the House of Representatives to discuss this draft based on the stages in the discussion up to the enactment of a law. This Job Creation Law was drafted without considering the principles regulated in law. Even legislators arbitrarily make rules to change laws that are contrary to law. Because if you look at the process of establishing the Job Creation Law that is contrary to the principles of forming a good law and it is problematic at the planning and drafting stages, it is necessary to submit a Judicial Review to the Constitutional Court. 


\section{REFERENCES}

Bagir Manan, Basics of Indonesian Legislation, (Jakarta: Ind-Hill-Co, 1992)

Jimly Asshiddiqie, Constitutional Law and Pillars of Democracy, Second Edition, (Jakarta: Sinar Grafika, 2012)

Lutfil Ansori, Legal Drafting: Theory and Practice of Formulating Legislative Regulations, (Depok: Rajawali Pers, 2019)

Mahfud MD., Constitution and Law in Controversial Issues, (Jakarta: Rajawali Pers, 2009)

Maria Farida Indrati Soeprapto, Legislation: Types, Functions, and Content of Content, Kanisius, Yogyakarta, 2010

Mochtar Kusumaatmadja, Concepts of Legal Development in Development, (Bandung: Alumni, 2002)

Maria Farida Indrati Soeprapto, Legislation: Types, Functions and Content of Contents, Kanisius

1945 Constitution of the Republic of Indonesia

Law of the Republic of Indonesia Number 12 of 2011 concerning the Establishment of Legislative Regulations.

Law of the Republic of Indonesia Number 11 of 2020 concerning Job Creation

CNBC Indonesia, https://www.cnbcindonesia.com/news/20200212114420-47233 / today-draft-omnibus-law-cilaka-submitted-to-dpr, accessed on 10 November 2020 at 13:20 WIB.

Paulus Aluk Fajar Dwi Santo, Understanding the Idea of Omnibus Law, https://businesslaw.binus.ac.id/2019/10/03/mem]-gagasan-omnibus-law, accessed on 10 November 2020 at 13:34 WIB 